\title{
Role of Macrophages in Cardioprotection
}

\author{
Jonathan Yap ${ }^{1,+}{ }^{\dagger}$, Hector A. Cabrera-Fuentes ${ }^{2,3,4,5,6, *,+}$, Jason Irei ${ }^{1}$, Derek J. Hausenloy $3,5,7,8,9$ \\ and William A. Boisvert 1,6,*(D) \\ 1 Center for Cardiovascular Research, John A. Burns School of Medicine, University of Hawaii, Honolulu, \\ HI 96813, USA; jktyap@hawaii.edu (J.Y.); jasonsi@hawaii.edu (J.I.) \\ 2 Tecnologico de Monterrey, Centro de Biotecnologia-FEMSA, Monterrey, NL 264610, Mexico \\ 3 National Heart Research Institute Singapore, National Heart Centre, Singapore 169609, Singapore; \\ d.hausenloy@ucl.ac.uk \\ 4 Cardiovascular and Metabolic Disorders Program, Duke-National University of Singapore Medical School, \\ Singapore 169857, Singapore \\ 5 Institute of Biochemistry, Medical School, Justus-Liebig University, 35392 Giessen, Germany \\ 6 Institute of Fundamental Medicine and Biology, Kazan (Volga Region) Federal University, \\ 420008 Kazan, Russia \\ 7 Yong Loo Lin School of Medicine, National University Singapore, Singapore 117597, Singapore \\ 8 The Hatter Cardiovascular Institute, University College London, London WC1E 6HX, UK \\ 9 The National Institute of Health Research University College London Hospitals Biomedical Research Centre, \\ Research \& Development, London W1T 7DN, UK \\ * Correspondence: hacafu@tec.mx (H.A.C.-F.); wab@hawaii.edu (W.A.B.); \\ Tel.: +52-1-81-2351-5933 (H.A.C.-F.); +1-(808)-692-1567 (W.A.B.) \\ + These authors contributed equally to this work.
}

Received: 31 March 2019; Accepted: 17 May 2019; Published: 19 May 2019

\begin{abstract}
Cardiovascular diseases are the leading cause of mortality worldwide. It is widely known that non-resolving inflammation results in atherosclerotic conditions, which are responsible for a host of downstream pathologies including thrombosis, myocardial infarction (MI), and neurovascular events. Macrophages, as part of the innate immune response, are among the most important cell types in every stage of atherosclerosis. In this review we discuss the principles governing macrophage function in the healthy and infarcted heart. More specifically, how cardiac macrophages participate in myocardial infarction as well as cardiac repair and remodeling. The intricate balance between phenotypically heterogeneous populations of macrophages in the heart have profound and highly orchestrated effects during different phases of myocardial infarction. In the early "inflammatory" stage of MI, resident cardiac macrophages are replaced by classically activated macrophages derived from the bone marrow and spleen. And while the macrophage population shifts towards an alternatively activated phenotype, the inflammatory response subsides giving way to the "reparative/proliferative" phase. Lastly, we describe the therapeutic potential of cardiac macrophages in the context of cell-mediated cardio-protection. Promising results demonstrate innovative concepts; one employing a subset of yolk sac-derived, cardiac macrophages that have complete restorative capacity in the injured myocardium of neonatal mice, and in another example, post-conditioning of cardiac macrophages with cardiosphere-derived cells significantly improved patient's post-MI diagnoses.
\end{abstract}

Keywords: macrophages; cardioprotection; innate immune response; myocardial infarction; cardiac repair; remodeling

\section{Cardiovascular Disease and Global Burden}

Cardiovascular diseases (CVD) are the leading cause of death and disability worldwide [1]. CVD are a class of diseases which affect the heart, blood vessels, and the vasculature of the 
brain [1]. CVD include but are not limited to atherosclerosis, heart disease, ischemic heart disease, cerebrovascular disease, ischemic stroke, hemorrhagic stroke, hypertensive heart disease, cardiomyopathy and myocarditis, atrial fibrillation and flutter, aortic aneurysm, peripheral vascular disease, and endocarditis [2]. According to 2015 mortality data, CVD claimed an estimated 17.9 million deaths globally, more than cancer and chronic lower respiratory disease combined [3]. Disability adjusted life-years (DALYs), is a measurement for the number of years lost due to illness, disability, and early death. In 2016, global CVD burden was estimated to be 353 million DALYs compared to 308 million DALYs in 2000 [4].

\section{Overview of Atherosclerosis}

Atherosclerosis is an inflammatory disease characterized by the hardening and narrowing of an artery due to the accumulation of lipids, immune cells, ribonucleic acids and various fibrous elements [5-8]. Over time these accumulations develop into atherosclerotic plaques that can occlude blood vessels resulting in reduced blood flow and may lead to acute thrombotic complications [9-14]. Thrombotic events arise when vulnerable plaques rupture, exposing vascular structures to circulation setting off a coagulation cascade forming a thrombus [12,15]. This thrombus may either form a stationary blockage completely occluding the blood vessel leading to symptoms of acute ischemia, or break loose from the initial formation site and become lodged elsewhere potentially resulting in myocardial infarction (MI), pulmonary embolism (PE), or stroke [12,16-21]. As extensively described in this review, macrophages play a central role in stoking inflammation in the cardiovascular network. Recent clinical studies aimed at attenuating inflammation in CVD through inhibition of IL- $1 \beta$ is a powerful testament to the importance of inflammation in CVD [22,23].

\section{Macrophage Roles in Thrombus Formation}

Early development and progression of atherosclerosis predominantly occurs within arterial areas which experience disturbed laminar flow such as arterial branch points and bifurcations [24]. In these areas, low-density lipoprotein (LDL) and apolipoprotein B-containing lipoproteins accumulate within the sub endothelial space where they are subject to modification by reactive oxygen species (ROS) and various enzymes [11,24-27]. Monocytes infiltrate the vascular intima, differentiate into macrophages, and phagocytize modified LDL within the surrounding tissues. Macrophages are unable to regulate metabolism of modified lipid species and become lipid-laden foam cells leading to dysregulation of inflammatory signaling, endoplasmic reticulum (ER) stress, and eventually cell death [28-33]. Proliferation of smooth muscle cells assist in the formation of a fibrous cap on the luminal side of the plaque, contributing to plaque stability [34]. As atherosclerosis progresses, disruption of macrophage-mediated efferocytosis fails to effectively clear cellular debris and oxidized lipids, leading to the development of a necrotic core within the plaque $[24,35,36]$. Metabolically dysfunctional macrophages together with necrosis, release proteolytic enzymes capable of thinning the protective fibrous cap $[24,37,38]$. Matrix metalloproteinases (MMPs) produced by macrophages can degrade various types of extracellular matrix (ECM) proteins [24]. MMP-2 and MMP-9 are hypothesized to play a role in fibrous cap thinning and plaque rupture $[13,24,39]$. Rupture of an atherosclerotic plaque may lead to life threatening conditions such as a myocardial infarction, stroke, pulmonary embolism, and limb ischemia [12,19,21,40,41]. Recent evidence has demonstrated that macrophage interactions with platelet-derived chemokines play a crucial role in atherothrombotic risk. CXCL4 is released from platelet alpha granules which stimulates the release of other store proteins including the chemotactic cytokines; CCL3 (MIP-1 $\alpha$ ), CCL5 (RANTES), and CCL7 (MCP-3) [42-44]. Transcriptomics revealed that CXCL4 induces a novel alternatively activated macrophage termed "M4", and data has also shown that M4 macrophages are significantly associated with atherosclerotic plaque stability and vascular inflammation [45-47].

While the majority of MI events occur as a function of fibrous cap rupture due to inflammatory and proteolytic degradation by macrophages and constituents of the necrotic core, another phenotype 
of $\mathrm{MI}$ is responsible for nearly $30 \%$ of all thrombotic events and results from plaque erosion and thrombus formation without rupture of the fibrous cap [48,49]. And although macrophages have long been accepted as the purveyor of MI, studies have shown that plaque erosion is associated with less lipid/plaque burden, a greater abundance of smooth muscle cells, and a comparatively small macrophage population [50-53]. Consequences of such limited macrophage content associated with plaque erosion in contrast to macrophage-dependent plaque rupture have yet to be determined, and the mechanism of erosion vs. rupture requires further exploration.

\section{Macrophages: Inflammation and Activation}

As the macrophage is the predominant cell type in all stages of atherosclerosis, phenotypic heterogeneity and functional plasticity are fundamental to a given inflammatory response. Resolving inflammation is a regulated inflammatory process which relies on immune cells to maintain systemic homeostasis [54]. This is accomplished by immediate elimination of foreign pathogens, resolution of sterile inflammation by removal of endogenous pathogens, and maintenance of proper wound healing and tissue repair [55]. Following the clearance of inflammatory elements, most macrophages leave the inflammatory site or undergo apoptosis [56]. In contrast, non-resolving inflammation is chronic in nature as its underlying cause persists for an extended period of time [57]. Cancer, arthritis, and atherosclerosis are all examples of non-resolving inflammation in which infiltration and accumulation of monocytes, dendritic cells, and macrophages induce a continuous inflammatory cascade [58-60]. The physiological environment is responsible for generating different subtypes of macrophages that display varying degrees of activation. Macrophage activation produces distinct functional phenotypes that are most commonly categorized using the Th1/Th2 T cell polarization paradigm, whereby M1 macrophages are representative of pro-inflammatory characteristics and M2 macrophages are associated with tissue repair and wound healing [61,62]. Clearly, this is an overly simplistic view of macrophage behavior. However, the general guidelines that advise the M1 and M2 nomenclature are useful as a basic delineation of macrophage phenotypes.

M1 macrophages are described as being "classically" activated. M1 activation of macrophages can be initiated by recognition of pathogen-associated molecular patterns (PAMPs) like lipopolysaccharide, chitin, and other intracellular pathogens. In addition, damage-associated molecular patterns (DAMPs) resulting from tissue/cell damage and necrosis are also capable of promoting inflammation. Typically, PAMPs and DAMPs bind to pattern recognition receptors (PRRs) located on the surface of macrophages. Toll -like receptors (TLRs) are one of five types of PRRs associated with macrophage activation [63-66]. During an innate immune response, TLR agonists engage the MYD88-dependent pathway including IRAK4, TRAF6, and IKK $\beta$ ultimately leading to activation of NF- $\mathrm{KB}$. The inflammatory function of this pathway in $\mathrm{M} 1$ macrophages is essential to innate immunity in response to pathogenic stimuli. NF- $\mathrm{KB}$ activity in M1 macrophages results in transcription of pro-inflammatory cytokines: IL-1B, IL-6, IL-12, TNF- $\alpha$, as well as chemokines involved in immune cell recruitment and invasion. M1 macrophages also encourage differentiation of inflammatory T-cell phenotypes which further participate in mediating inflammation $[67,68]$. IFN- $\gamma$ is also known to promote M1 activation. It is a potent microbicidal, cytotoxic effector that is transiently produced by natural-killer cells (NK) and sustained production is achieved by Th- 1 cells. IFN- $\gamma$ relies on the JAK/STAT signaling pathway which is initiated by receptor-ligand interaction with IFN- $\gamma$ receptor 1 and 2 (IFNGR1/2) [69]. It has recently been shown that IFN- $\gamma$ and TLR mediated signaling pathways have a synergistic effect on promoting the M1 macrophage phenotype with tumoricidal function. The resultant macrophage population produces nitric oxide (NO), TNF- $\alpha$, IL-12p40, and IL-12p70 while the presence of IFN- $\gamma$ suppressed macrophage secretion of IL-10 is induced by TLR agonists [70]. During the innate immune response, classically activated macrophages produce pro-inflammatory cytokines which play a key role in host defense. However, prolonged exposure to such compounds can result in extensive damage to the host. This is the case in various inflammatory diseases [71-73]. 
Alternatively activated macrophages (M2) are characterized as having proliferative and wound healing properties. M2 macrophages promote collagen synthesis, fibrosis, and other tissue remodeling functions [74]. Further, this macrophage phenotype displays elevated expression of scavenger receptors $(\mathrm{SR})$, mannose receptors (MR), and galactose receptors. Alternatively activated macrophages secrete cytokines: Transforming growth factor- $\beta$ (TGF- $\beta$ ) and IL-10, chemokines: CCL17, CCL22, CCL24, and the enzyme arginase-1 in mice (ARG 1), which participates in cell proliferation, collagen formation, and tissue repair [74-76]. M2 polarization of macrophages is commonly accomplished by stimulation of the glucocorticoid receptor (GCR), IL-10 receptor (IL-10R1), and antigens recognized by the Fc family of receptors [76]. IL-4 and IL-13-mediated alternative activation represents the most extensively studied variation of M2-macrophage plasticity. Both of these Th 2-related cytokines are expressed by T cells, B cells, mast cells, and macrophages. Aside from down regulating many of the cytokines associated with M1 activation, IL-4 and IL-13 induce fibrogenesis through expression of fibronectin-1 (FN-1) and beta 2 integrins. They also modulate tissue repair and cell proliferation signaling via insulin-like growth factor 1 (IGF-1) [77,78]. Aberrant expression of IL-4 and IL-13 has been associated with fibrosis in different disease states and tissues $[79,80]$. The term "alternative activation" refers to any activation state other than "classically" activated. Therefore, it should be noted that alternatively activated macrophages exhibit a growing spectrum of phenotypic and functional varieties. M2 macrophages can be induced by different stimuli as previously mentioned, and accordingly have specific classifications denoted by the stimulus and effector function. M2a macrophages are elicited by Th- 2 cytokines, IL- 4 and IL-13 while M2b activation is triggered by $\mathrm{Fc}-\gamma$ receptors and TLR stimulation, and M2c macrophages can be obtained by GC, IL-10, or TGF- $\beta$ ligands [81].

\section{Cardiac Macrophages}

Tissue-resident macrophages have been identified in a number of different organs where they engage in maintaining homeostatic conditions and tissue regeneration. Mouse models have demonstrated that tissue-resident macrophages found in the liver, brain, lung, skin, and heart derive from an embryonic lineage, distinct from those of monocytic progenitors [82-87]. These studies and others also highlight the observation that tissue-resident macrophages maintain a self-proliferative population throughout adulthood, which is independent of monocyte-derived macrophage recruitment and declines with age [88-90]. The majority of resident cardiac macrophages were found to be established prior to birth, and yolk sac progenitors are the primary source of this cell population [91]. Essentially, the development of advanced gene fate-mapping techniques has shown that, in the steady-state, two resident cardiac macrophage subsets are present: MHC-IIlowCCR2- and MHC-IIhighCCR2- cells. Resident cardiac macrophages replenish through tissue proliferation, and comprise the largest subpopulation of cardiac macrophages [91,92]. Under inflammatory conditions, a third macrophage subtype can be found in the heart and is classified as MHC-IIhighCCR2+ cells. Originating completely from bone marrow-derived monocytes, the population of this macrophage subtype is recruited during inflammation and ultimately replaces embryo-derived cardiac macrophages as their proliferative properties diminish with age [91,93]. Circulating CCR2+ monocytes interact with the CCR2 ligand, MCP-1 (CCL2), which is a chemotactic cytokine that potentiates macrophage recruitment and invasion [94]. Cardiac tissue injury initiates an influx of CCR2+ macrophages which produce IL-1 $\beta$, pro-inflammatory cytokine associated with atherosclerosis [22,91]. On the other hand, resident CCR2- macrophages primarily originating from an embryonic progenitor facilitate processes of angiogenesis and cardiomyocytes proliferation, roles that are similar in developmental and neonatal macrophages $[95,96]$. Bajpai et al. demonstrated that the depletion of resident cardiac CCR2- macrophages in a murine model of myocardial infarction increased infarct area, reduced left ventricular (LV) systolic function, and exaggerated LV remodeling [97]. Another study investigated the therapeutic potential of resident cardiac macrophages by administering a selective CCR2 inhibitor in a mouse model of cardiac injury. CCR2 inhibition blocked monocyte recruitment and preserved the populations of MHC-IIlowCCR2- and MHC-IIhighCCR2- resident cardiac macrophage subsets. As a 
result, decreased mRNA and protein expression of MCP-1, IL-1- $\beta$, IL-6, and TNF- $\alpha$ was observed in injured mice that received the CCR2 inhibitor compared to vehicle control [96]. Further exploration into resident cardiac macrophages as a target for improved outcomes after myocardial infarction is indeed warranted.

Monocyte-derived macrophages are characterized as MHC-IIhighCCR2+ cells which are highly recruited to the heart under atherosclerotic conditions and following myocardial insult. As atherosclerosis develops and progresses, monocytes are recruited to lesions where they accumulate and contribute to atheromatous plaque formation. Unlike Ly- $6 C^{\text {Low }}$ monocytes which are far less invasive, Ly-6 $\mathrm{C}^{\mathrm{High}}$ monocytes induce excessive monocytosis, accumulate in lesions, and differentiate into macrophages [98,99]. Ly-6 $\mathrm{C}^{\text {High }}$ Monocytes are inflammatory and rely on CCR2, CCR5, and CX3CR1 to infiltrate plaque sites [100]. Further, Combadière et al. found that inhibition of CCL2, CCR5, and CX3CR1 abrogated monocytosis and trafficking of Ly-6CHigh monocytes, which abolished atherosclerosis by up to $90 \%$ in hypercholesterolemic mice [101].

\section{Macrophages in Homeostasis}

In the healthy heart, mouse models reveal the presence of a significant number of resident cardiac, yolk sac-derived MHC-IIlowCCR2- and MHC-IIhighCCR2- macrophages expressing low levels of Ly-6C and exhibiting an M2 polarization profile [102]. It has recently been demonstrated that local proliferation of these resident tissue macrophages is the major source of cardiac macrophages in the steady-state [91,103]. Data published by Epelman et al. utilized the proliferation marker Ki-67 to demonstrate the rapid proliferation of resident cardiac macrophages in the heart after MI, while proliferative activity is completely ablated in monocytes recruited from the circulation once they have differentiated into macrophages [91]. Conversely, experimental mouse models have revealed that circulating monocytes contribute to inflammatory mechanisms that precede different forms of cardiac pathology. SiRNA silencing of CCR2 mRNA in monocytes prevented monocyte accumulation in inflammatory regions and in atherosclerotic plaques, and reduced infarct size after coronary artery occlusion [104]. Resident cardiac MHC-IIlowCCR2- and MHC-IIhighCCR2- macrophages express high levels of myeloid epithelial reproductive tyrosine kinase (MerTK), a critical receptor involved in macrophage efferocytosis. Deficiency of this protein results in inefficient removal of cell debris during cardiac repair, increased infarct size, and depressed cardiac function [105].

\section{Macrophages in the Aging Heart}

As is the case with most diseases and disorders, age is a major risk factor in cardiac-related morbidity and mortality. Aging in the heart is often characterized by a number of dysfunctional conditions including: Myocardial sarcopenia, hypertrophy, vascular hyperpermeability, fibrosis, inflammation, and functional impairment [106-108]. Direct changes in the myocardium and not ventricular load as a result of hypertension is responsible for such alterations in heart condition and function [109]. Employing genetic fate-mapping techniques along with parabiotic and chimeric bone marrow mouse models, Molawi et al. essentially demonstrated that the self-renewal of yolk sac-derived resident macrophages declines with age. Thus, population dynamics in the aging heart shifts in favor of monocyte-derived macrophages even in the absence of inflammation [93]. These examples represent a collective body of data that grows more compelling with the assertion that resident cardiac macrophages hold much potential in the way of therapeutic intervention for a wide array of cardiac disorders.

\section{Pathology and Resolution of Myocardial Infarction}

Myocardial infarction (MI) is one of many pathological etiologies associated with cardiovascular disease. In the pathologic context MI is defined as cardiomyocyte death due to ischemic insult. Such events occur as a function of an imbalance in the relation between myocardial oxygen supply and demand. The continuous development of atherosclerotic plaque in the vasculature results in occlusion 
of the vessel lumen. Luminal narrowing of $\geq 75 \%$ can go undetected while at rest, but as oxygen demands increase with activity, the obstructed blood flow does not allow for proper oxygenation of tissues. The most common underlying cause of $\mathrm{MI}$ is the incidence of plaque instability in atherosclerotic disease [110]. Stability in the atheromatous plaque is dependent on the structural integrity of the fibrous cap. Plaque rupture or erosion introduces thrombi into the circulation where they can cause thrombotic embolism and acute MI [111]. Occlusion of coronary blood flow prevents aerobic metabolism leading to rapid ATP depletion and metabolite accumulation. Critical systolic dysfunction is observed within seconds of ischemic insult and has been shown to cease entirely after $60 \mathrm{~s}[112,113]$. The effects of ischemic insult are completely reversible so long as the duration is $<15-20 \mathrm{~min}$. In large animal models, prolonged periods of ischemia (60 Minutes) causes continuous cell death of cardiomyocytes in the ischemic region [114-116]. After a significant MI, cardiomyocytes undergo extensive cell death. The mammalian heart has only limited regenerative capacity, and therefore the large number of deceased cells are replaced by non-contractile scar tissue derived from collagen and ECM production. Although this scar tissue is largely nonfunctional, it is crucial to the maintenance of cardiac structural integrity and organ function. This reparative process following MI generally takes place in a two-tiered fashion; an inflammatory stage in which a massive influx of immune cells are recruited to the ischemic region where macrophages and neutrophils mediate efflux of necrotic debris, and a reparative/proliferative phase that involves the release of growth factors accompanied by extracellular matrix formation, collagen synthesis, and scarring [117-121]. Dysregulation of the inflammatory response associated with severe MI can result in adverse remodeling, increased risk of repeat events, and pervasive fibrosis that ultimately compromises cardiac function [122].

\section{Macrophages in Myocardial Infarction}

As previously mentioned, cardiac macrophages are of two distinct lineages: Yolk sac-derived MHC-IIlowCCR2- and MHC-IIhighCCR2- macrophages and MHC-IIhighCCR2+ monocyte-derived macrophages. Over time, resident developmental macrophages are progressively replaced by macrophages differentiated from bone marrow-derived and splenic monocytes. Macrophages are among the most abundant cell types in the infarcted heart. Circulating monocytes from the bone marrow and spleen are recruited to the infarcted area, and experimental evidence demonstrates the importance of MCP-1 and its receptor, CCR2, in the process of leukocytosis [123,124]. The monocyte response to $\mathrm{MI}$ proceeds in a biphasic manner whereby distinct monocyte phenotypes are responsible for the expression of CCR2 by damaged cells. MI initiates recruitment of Ly-6C ${ }^{\text {High }}$ monocytes from the bone marrow and spleen to the infarcted region. This inflammatory monocyte subtype is highly invasive and is among the first cells to arrive at the infarct zone. Ly- $6 \mathrm{C}^{\text {High }}$ monocyte numbers reach their peak approximately three days after injury [125]. From days 1-3 monocytosis facilitates the influx of monocytes which accumulate and differentiate into macrophages. This is referred to as the inflammatory phase in which macrophages and neutrophils clear dead cells and cell debris. The reparative phase is a result of proper resolution of the inflammatory phase, and is characterized by phenotypic transition of inflammatory monocytes and macrophages (Ly-6C $\mathrm{C}^{\text {High }}$ monocytes and M1 macrophages) to the anti-inflammatory subtypes of the cells (Ly-6 $\mathrm{C}^{\mathrm{Low}}$ monocytes and M2 macrophages). Over the ensuing days fibroblasts proliferate contributing to scar formation. Revascularization of tissues is initiated by monocyte/macrophage production of vascular endothelial growth factor (VEGF) and TGF- $\beta[96,125]$. Disfunction of either phase can have profoundly deleterious effects and understanding the mechanics of these elegantly orchestrated processes is essential to the development of novel therapeutic interventions.

As early as $30 \mathrm{~min}$ after MI, Ly-6 $\mathrm{C}^{\mathrm{High}}$ monocytes are recruited from the circulation and infiltrate the infarct zone via MCP-1/CCR2 interactions [126]. Monocyte numbers reach their peak at around day three at which point they accumulate and undergo differentiation into macrophages. Determination between monocytes and macrophages in mouse models is achieved by the differential expression of F4/80/I-A ${ }^{\mathrm{b}} / \mathrm{CD} 11 \mathrm{c}$ as well as CD64 and MerTK. Monocytes are classified as F4/80/I-A ${ }^{\mathrm{b}} / \mathrm{CD} 11 \mathrm{c}^{\mathrm{Low}}$ 
and express only CD64, while macrophages are F4/80/I-A $/$ CD11 $\mathrm{c}^{\text {High }}$ and express both MerTK and CD64 [91,125,127]. Between days 5-7 macrophage populations within the infarct are at their maximum as illustrated by a mouse model of MI [128,129]. At this stage, classically activated macrophages dominates the cell population of the infarcted area. M1 macrophages secrete pro-inflammatory cytokines like TNF- $\alpha$, IL-1 $\beta$, IL- 6 and MMPs, thereby enhancing the pro-inflammatory response and facilitating breakdown of collagen and ECM. It is postulated that pro-inflammatory macrophages play an integral role in preparing the infarcted tissue for repair by removing apoptotic immune cells, dead monocytes, cell debris, and ECM components [130]. The post-MI inflammatory phase gradually subsides and macrophages are again a focal cell type in the process of wound healing. Phagocytosis by macrophages is required for proper initiation of the post-MI wound healing response [131]. Inadequate suppression or extended duration of the pro-inflammatory response that occurs after MI can have serious pathological consequences that include: Cardiomyocyte death, impaired systolic function, chamber dilation due to extensive matrix degradation, compromised ventricular wall integrity, cardiac rupture, and fibrosis [132].

\section{Macrophages and Tissue Repair after MI}

The proliferative phase after MI is demarcated by a shift in the polarization profile of macrophages in the infarcted zone from M1 to M2 phenotype. Depletion of cardiac macrophages with clodronate showed that both M1 and M2 macrophage phenotypes are present in the infarcted area and contribute to tissue remodeling, albeit with divergent roles and effects [128]. A second "wave" of monocytosis takes place once the initial inflammatory phase recedes. The pool of cardiac macrophages is replenished as Ly- $6 C^{\text {Low }}$ monocytes are extensively recruited to infarcted tissues where they accumulate and undergo differentiation into alternatively activated macrophages. M2 macrophages secrete IL-10, which depresses the pro-inflammatory effects of M1 macrophages, and TGF- $\beta$; a cytokine that initiates tissue remodeling and angiogenesis. Shirishi et al. utilized a mouse model with a deletion of the Trib1 gene. This model of impaired M2 macrophage activation allowed them to determine cell type-specific effects of M2 macrophage depletion on post infarct remodeling. When compared to control animals, $\mathrm{Trib}^{-/}$ mice exhibited severely diminished reparative function following MI, including: Reduced collagen synthesis and resultant cardiac rupture. The impaired healing process was completely rescued by the introduction of exogenous M2 macrophages. Furthermore, it was shown that administration of IL-4, which is a well-known activator of M2 macrophages also rescued the dysfunctional genotype [133]. Macrophage heterogeneity in the post-MI heart has profound implications on its ability to promote healing and retain functionality.

\section{Macrophage-Targeted Pharmaceutical Interventions}

Statins are a class of drugs that inhibit the liver enzyme $\beta$-hydroxy $\beta$-methylglutaryl-coenzyme $\mathrm{A}$ (HMG-CoA) reductase. This effect is designed to reduce the development of atherosclerotic plaque and protect from repeat infarction [134]. Aside from there lipid lowering qualities, statins have exhibited anti-thrombotic and anti-inflammatory properties [135]. Kwak et al. found that pravastatin inhibited IFN- $\gamma$-induced macrophage activation [136]. It was also demonstrated by Ghittoni et al. that simvastatin interrupted MHC class II interactions between macrophages and the adaptive immune complex [137].

ACE inhibitors (ACEi) have also been highlighted as possible cardioprotective pharmaceutical therapies. While it's original usage was prescribed to inhibit circulating angiotensin II (ATII) to concentration, it also mitigates the pro-inflammatory effects of ATII [138-140]. In murine mouse models, enalapril reduced ATII-stimulated monocyte recruitment from splenic reservoirs into the myocardium during MI and subsequently improved ejection fraction by $14 \%$, while at the same time mitigating vascular inflammation [141]. In a separate study, enalapril administered after MI resulted in significant reduction in plasma levels of MCP-1 and reduced accumulation and activation of both monocytes and macrophages in patients with MI [142]. 


\section{Cell-Mediated Cardioprotection in MI}

As mentioned earlier in this review, yolk sac-derived, MHC-IIlowCCR2- and MHC-IlhighCCR2macrophages are the predominant immune cell type in the healthy heart. This unique population of macrophages decreases with aging and after MI, when they are replaced by the bone marrow derived macrophages (BMDM) via the circulation. This subset of resident, cardiac-tissue macrophages resembles the M2 phenotype and displays cardioprotective attributes post-MI [133]. Although proper infarct healing involves the formation of a functional scar, it has been observed in murine neonates that the distinct population of resident embryonic macrophages is capable of complete restorative repair $[96,143]$. Newly published work by Dick et al. revealed the importance of resident cardiac macrophages in proper remodeling. [144] The authors utilized a Cxcr1-based method of macrophage depletion coupled with a green fluorescent protein (GFP) label that enabled specific phenotype selection and cell mapping. Despite accounting for only $2-5 \%$ of the cardiac macrophage population during the initial weeks post MI, depletion of the cells prevented normal infarct healing and adversely affected cardiac function. And while recruited macrophages were nearly identical to the depleted resident macrophages, they were unable to adopt the same phenotypic specificity [144]. Clearly, resident cardiac macrophages are a novel method of cell-mediated cardio protection. Further work is necessary to better understand what clinical applications these cells may hold.

\section{Cardioprotection through Cellular Post-Conditioning}

The well-regulated involvement of macrophages in each phase of MI suggests that interactions with other cell types affect macrophage behavior. In another example of cell therapy for MI, investigators have found that paracrine signaling from cardiosphere-derived cells (CDC) modulate macrophage activation promoting a phenotypic switch from M1 to M2 $[145,146]$. CDCs are essentially cardiac mesenchymal stem cells. Moreover, they exhibit clonogenicity and the potential for multi-lineage differentiation [147]. Multiple animal models have been used to examine the efficacy of CDCs in cellular post-conditioning as a means of ameliorating MI-associated pathology [148]. Intra-coronary infusion of CDCs resulted in decreased infarct size and reduced microvascular occlusion after $48 \mathrm{~h}$ in a porcine model [149]. Similarly, a mechanistic study performed in rats with acute MI found that intracoronary infusion of CDCs after $20 \mathrm{~min}$ of reperfusion resulted in diminished infarct size and a greater degree of functional recovery. Further, these authors showed that CDCs promoted the alternative activation of macrophages toward a cardioprotective phenotype. Macrophages preconditioned with CDCs were also adoptively transferred after reperfusion and effectively reduced infarct size. Thus, illustrating the interplay between various cells involved in cardiac preconditioning [146]. While the relationship between CDCs and macrophages has only recently been studied, the efficacy and safety of CDCs has been well documented in animal and human subjects [150-153]. Cellular post-conditioning is especially attractive because of its ability to be administered after an MI event has occurred. Encouraging results and a growing breadth of insight regarding CDCs and macrophages hold much promise for this novel treatment.

\section{Concluding Remarks}

The dynamic mechanisms that govern tissue repair and wound healing are inextricably intertwined with those that mediate inflammation and immunity. The data reviewed here describes a tightly regulated sequence of events from infarction to remodeling that is dependent on different populations of macrophage phenotypes throughout the various stages of myocardial infarction, as summarized in Figure 1. Both M1 and M2 macrophages are required for healing cardiac tissue and preserving functional architecture. Cardioprotection is an intriguing therapeutic technique. However, numerous publications have exposed the elusive nature of this concept. Recent studies are reintroducing much-needed enthusiasm into understanding the cardioprotective potential of cardiac macrophages. 
As insight beckons effort and innovation, it is imperative that we expand our comprehension of macrophage contributions to cardiac health.

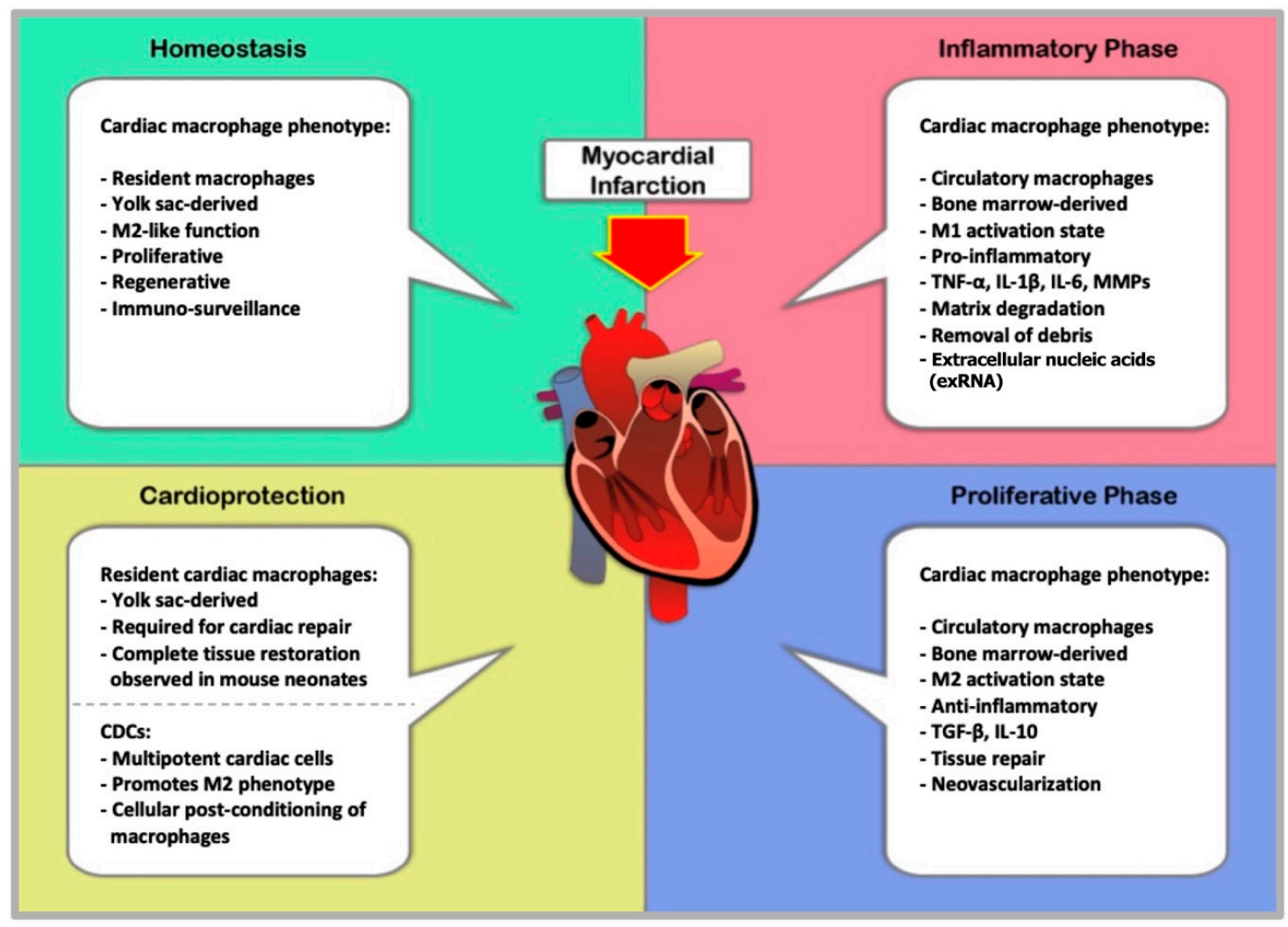

Figure 1. The Cardiac macrophage population, while the heart is in homeostasis, consists primarily of yolk sac-derived macrophages. However, these resident tissue macrophages diminish in number with age and are replaced by circulating bone marrow-derived monocytes even in the absence of inflammation. BMDM replenish the cardiac macrophage supply, and exhibit M2 activation in the steady-state heart. The inflammatory phase of acute myocardial infarction initiates an immune response by monocytes/macrophages, which are recruited to the injured tissue. Ly6CHigh monocytes infiltrate and accumulate in the injured area where they differentiate into "classical" M1 macrophages. M1 macrophages secrete pro-inflammatory cytokines and MMPs upon activation by DAMPs. The inflammatory response peaks at around day 5-7 and ultimately results in clearance of dead cells and cell debris, processes essential for tissue repair. Resolution of inflammation after MI marks the beginning of a proliferative phase. During which, circulating Ly6CLow monocytes infiltrate the infarcted area. Thus, the population of cardiac macrophages begins to move toward alternative activation. The presence of M2 macrophages suppresses inflammation, enhances tissue repair and promotes angiogenesis by the expression of TGF- $\beta$ and IL-10. Dysregulation of either the inflammatory or proliferative phase can produce severe outcomes like ventricular weakening, fibrosis, and compromised function. Macrophages can participate in cardioprotection via cell-mediated mechanisms. For example, yolk sac-derived cardiac macrophages are required for reparative mechanisms of wound healing. Further, the identical phenotype in murine neonates has full regenerative capacity after MI and remains through adulthood although it diminishes greatly over time and post-MI. CDCs are another example of cellular cardioprotection. The cardiac type of mesenchymal stem cell, CDCs have the potential to induce M2 activation in macrophages. Post-conditioning of macrophages with CDCs results in an alternatively activated phenotype, which has been shown to improve prognosis following myocardial infarction. Abbreviations: BMDM; bone marrow derived macrophages, DAMP; damage associated molecular pattern, MMP; metallo-matrix proteinase; IL-10; interleukin-10, TGF- $\beta$; transforming growth factor- $\beta$, CDC; cardiosphere-derived cells. 
Funding: This research was funded by National Institutes of Health grants R01HL081863, by Innovative Research Grant 16IRG27540027 and Grant-in-aid 16GRNT30810007 from the American Heart Association, and by the Ingeborg v.F. McKee Fund of the Hawaii Community Foundation 17ADVC-86287 to WAB. JY was supported by the National Institutes of Health grant F31HL139082. DJH was supported by the British Heart Foundation (CS/14/3/31002), the National Institute for Health Research University College London Hospitals Biomedical Research Centre, Duke-National University Singapore Medical School, Singapore Ministry of Health's National Medical Research Council under its Clinician Scientist-Senior Investigator scheme (NMRC/CSA-SI/0011/2017) and Collaborative Centre Grant scheme (NMRC/CGAug16C006), and the Singapore Ministry of Education Academic Research Fund Tier 2 (MOE2016-T2-2-021). HACF was supported by the SHF-Foundation (SHF/FG657P/2017) and by the von Behring-Röntgen-Foundation (Marburg, Germany). Part of this work was performed within the Russian Government Program of Competitive Growth of Kazan Federal University. This article is based upon work from COST Action EU-CARDIOPROTECTION CA16225 supported by COST (European Cooperation in Science and Technology).

Conflicts of Interest: The authors declare no conflict of interest.

\section{Abbreviations}

\begin{tabular}{|c|c|}
\hline CVD & Cardiovascular diseases \\
\hline DALYs & Disability adjusted life-years \\
\hline MI & Myocardial infarction \\
\hline PE & Pulmonary embolism \\
\hline LDL & Low-density lipoprotein \\
\hline ROS & Reactive oxygen species \\
\hline ER & Endoplasmic reticulum \\
\hline MMPs & Matrix metalloproteinases \\
\hline ECM & Extracellular matrix \\
\hline CXCLs & Chemokine (C-X-C motif) ligands \\
\hline CCLs & Chemokine ligands \\
\hline MIP & Macrophage Inflammatory Proteins \\
\hline RANTES & Regulated on Activation, Normal T Cell Expressed and Secreted - CCL5 \\
\hline MCP & Monocyte chemoattractant protein \\
\hline PAMPs & Pathogen-associated molecular patterns \\
\hline DAMPs & Damage-associated molecular patterns \\
\hline PRRs & Pattern recognition receptors \\
\hline TLRs & Toll-like receptors \\
\hline MYD88 & Myeloid differentiation primary response 88 \\
\hline IRAK-4 & Interleukin-1 receptor-associated kinase 4 \\
\hline TRAF & TNF receptor associated factor \\
\hline $\mathrm{IKK} \beta$ & IкB kinase $\beta$ \\
\hline$N F-\kappa B$ & Nuclear factor-kappa B \\
\hline ILs & Interleukins \\
\hline IFN & Interferon \\
\hline NK & Natural-killer cells \\
\hline $\mathrm{NO}$ & Nitric oxide \\
\hline SR & Scavenger receptors \\
\hline MR & Mannose receptors \\
\hline TGF- $\beta$ & Transforming growth factor- $\beta$ \\
\hline MHC-II & Major histocompatibility complex class II molecules \\
\hline CCR & Chemokine receptors \\
\hline ARG 1 & Arginase-1 \\
\hline GCR & Glucocorticoid receptor \\
\hline FN-1 & Fibronectin-1 \\
\hline TRIB1 & Tribbles homolog 1 is a protein kinase \\
\hline VEGF & Vascular endothelial growth factor \\
\hline BMDM & Bone marrow derived macrophages \\
\hline CDC & Cardiosphere-derived cells \\
\hline GFP & Green fluorescent protein \\
\hline
\end{tabular}




\section{References}

1. Mendis, S.; Puska, P.; Norrving, B.; World Health Organization; World Heart Federation; World Stroke Organization. Global Atlas on Cardiovascular Disease Prevention and Control; World Health Organization in collaboration with the World Heart Federation and the World Stroke Organization: Geneva, Switzerland, 2011; p online resource (vi, 155p.).

2. Roth, G.A.; Johnson, C.; Abajobir, A.; Abd-Allah, F.; Abera, S.F.; Abyu, G.; Ahmed, M.; Aksut, B.; Alam, T.; Alam, K.; et al. Global, regional, and national burden of cardiovascular diseases for 10 causes, 1990 to 2015. J. Am. Coll. Cardiol. 2017, 70, 1-25. [CrossRef]

3. Benjamin, E.J.; Virani, S.S.; Callaway, C.W.; Chamberlain, A.M.; Chang, A.R.; Cheng, S.; Chiuve, S.E.; Cushman, M.; Delling, F.N.; Deo, R.; et al. Heart disease and stroke statistics-2018 update: A report from the american heart association. Circulation 2018, 137, e67-e492. [CrossRef] [PubMed]

4. Thomas, H.; Diamond, J.; Vieco, A.; Chaudhuri, S.; Shinnar, E.; Cromer, S.; Perel, P.; Mensah, G.A.; Narula, J.; Johnson, C.O.; et al. Global atlas of cardiovascular disease 2000-2016: The path to prevention and control. Glob. Heart 2018, 13, 143-163. [CrossRef] [PubMed]

5. Lusis, A.J. Atherosclerosis. Nature 2000, 407, 233-241. [CrossRef] [PubMed]

6. Simsekyilmaz, S.; Cabrera-Fuentes, H.A.; Meiler, S.; Kostin, S.; Baumer, Y.; Liehn, E.A.; Weber, C.; Boisvert, W.A.; Preissner, K.T.; Zernecke, A. Role of extracellular rna in atherosclerotic plaque formation in mice. Circulation 2014, 129, 598-606. [CrossRef]

7. Simsekyilmaz, S.; Cabrera-Fuentes, H.A.; Meiler, S.; Kostin, S.; Baumer, Y.; Liehn, E.A.; Weber, C.; Boisvert, W.A.; Preissner, K.T.; Zernecke, A. Response to letter regarding article "role of extracellular rna in atherosclerotic plaque formation in mice". Circulation 2014, 130, e144-e145. [CrossRef]

8. Ross, R. Atherosclerosis-An inflammatory disease. New Engl. J. Med. 1999, 340, 115-126. [CrossRef]

9. Zaman, A.G.; Helft, G.; Worthley, S.G.; Badimon, J.J. The role of plaque rupture and thrombosis in coronary artery disease. Atherosclerosis 2000, 149, 251-266. [CrossRef]

10. Munoz-Vega, M.; Masso, F.; Paez, A.; Carreon-Torres, E.; Cabrera-Fuentes, H.A.; Fragoso, J.M.; Perez-Hernandez, N.; Martinez, L.O.; Najib, S.; Vargas-Alarcon, G.; et al. Characterization of immortalized human dermal microvascular endothelial cells (hmec-1) for the study of hdl functionality. Lipids Health Dis. 2018, 17, 44. [CrossRef]

11. Liehn, E.A.; Ponomariov, V.; Diaconu, R.; Streata, I.; Ioana, M.; Crespo-Avilan, G.E.; Hernandez-Resendiz, S.; Cabrera-Fuentes, H.A. Apolipoprotein e in cardiovascular diseases: Novel aspects of an old-fashioned enigma. Arch. Med. Res. 2018, 49, 522-529. [CrossRef]

12. Badimon, L.; Vilahur, G. Thrombosis formation on atherosclerotic lesions and plaque rupture. J. Intern. Med. 2014, 276, 618-632. [CrossRef] [PubMed]

13. Yakala, G.K.; Cabrera-Fuentes, H.A.; Crespo-Avilan, G.E.; Rattanasopa, C.; Burlacu, A.; George, B.L.; Anand, K.; Mayan, D.C.; Corliano, M.; Hernandez-Resendiz, S.; et al. Furin inhibition reduces vascular remodeling and atherosclerotic lesion progression in mice. Arter. Thromb. Vasc. Biol. 2019, 39, 387-401. [CrossRef]

14. Falk, E. Pathogenesis of atherosclerosis. J. Am. Coll. Cardiol. 2006, 47, C7-C12. [CrossRef] [PubMed]

15. Liehn, E.A.; Cabrera-Fuentes, H.A. Inflammation between defense and disease: Impact on tissue repair and chronic sickness. Discoveries 2015, 3, e42. [CrossRef]

16. Cabrera-Fuentes, H.A.; Aragones, J.; Bernhagen, J.; Boening, A.; Boisvert, W.A.; Botker, H.E.; Bulluck, H.; Cook, S.; Di Lisa, F.; Engel, F.B.; et al. From basic mechanisms to clinical applications in heart protection, new players in cardiovascular diseases and cardiac theranostics: Meeting report from the third international symposium on "new frontiers in cardiovascular research". Basic Res. Cardiol. 2016, 111, 69. [CrossRef]

17. Hernandez-Resendiz, S.; Munoz-Vega, M.; Contreras, W.E.; Crespo-Avilan, G.E.; Rodriguez-Montesinos, J.; Arias-Carrion, O.; Perez-Mendez, O.; Boisvert, W.A.; Preissner, K.T.; Cabrera-Fuentes, H.A. Responses of endothelial cells towards ischemic conditioning following acute myocardial infarction. Cond. Med. 2018, 1, 247-258. [PubMed]

18. Cabrera-Fuentes, H.A.; Alba-Alba, C.; Aragones, J.; Bernhagen, J.; Boisvert, W.A.; Botker, H.E.; Cesarman-Maus, G.; Fleming, I.; Garcia-Dorado, D.; Lecour, S.; et al. Meeting report from the 2nd international symposium on new frontiers in cardiovascular research. Protecting the cardiovascular system from ischemia: Between bench and bedside. Basic Res. Cardiol. 2016, 111, 7. [CrossRef] [PubMed] 
19. Badimon, L.; Padro, T.; Vilahur, G. Atherosclerosis, platelets and thrombosis in acute ischaemic heart disease. Eur. Heart J. Acute Cardiovasc Care 2012, 1, 60-74. [CrossRef]

20. Rothwell, P.M. Atherothrombosis and ischaemic stroke. BMJ 2007, 334, 379-380. [CrossRef]

21. Oklu, R. Thrombosis. Cardiovasc. Diagn 2017, 7, S131-S133. [CrossRef]

22. Ridker, P.M.; Everett, B.M.; Thuren, T.; MacFadyen, J.G.; Chang, W.H.; Ballantyne, C.; Fonseca, F.; Nicolau, J.; Koenig, W.; Anker, S.D.; et al. Antiinflammatory therapy with canakinumab for atherosclerotic disease. N. Engl. J. Med. 2017, 377, 1119-1131. [CrossRef] [PubMed]

23. Ridker, P.M. Canakinumab for residual inflammatory risk. Eur. Heart J. 2017, 38, 3545-3548. [CrossRef] [PubMed]

24. Moore, K.J.; Tabas, I. Macrophages in the pathogenesis of atherosclerosis. Cell 2011, 145, 341-355. [CrossRef]

25. Williams, K.J.; Tabas, I. The response-to-retention hypothesis of early atherogenesis. Arter. Thromb. Vasc. Biol. 1995, 15, 551-561. [CrossRef]

26. Wouters, K.; Shiri-Sverdlov, R.; van Gorp, P.J.; van Bilsen, M.; Hofker, M.H. Understanding hyperlipidemia and atherosclerosis: Lessons from genetically modified apoe and ldlr mice. Clin. Chem Lab. Med. 2005, 43, 470-479. [CrossRef] [PubMed]

27. Li, D.; Mehta, J.L. Oxidized ldl, a critical factor in atherogenesis. Cardiovasc. Res. 2005, 68, 353-354. [CrossRef]

28. Moore, K.J.; Koplev, S.; Fisher, E.A.; Tabas, I.; Björkegren, J.L.M.; Doran, A.C.; Kovacic, J.C. Macrophage trafficking, inflammatory resolution, and genomics in atherosclerosis: Jacc macrophage in cvd series (part 2). J. Am. Coll. Cardiol. 2018, 72, 2181-2197. [CrossRef]

29. Hotamisligil, G.S. Endoplasmic reticulum stress and atherosclerosis. Nat. Med. 2010, 16, 396-399. [CrossRef]

30. Oh, J.; Riek, A.E.; Weng, S.; Petty, M.; Kim, D.; Colonna, M.; Cella, M.; Bernal-Mizrachi, C. Endoplasmic reticulum stress controls $\mathrm{m} 2$ macrophage differentiation and foam cell formation. J. Biol. Chem. 2012, 287, 11629-11641. [CrossRef]

31. Yu, X.H.; Fu, Y.C.; Zhang, D.W.; Yin, K.; Tang, C.K. Foam cells in atherosclerosis. Clin. Chim. Acta 2013, 424, 245-252. [CrossRef]

32. Kzhyshkowska, J.; Neyen, C.; Gordon, S. Role of macrophage scavenger receptors in atherosclerosis. Immunobiology 2012, 217, 492-502. [CrossRef] [PubMed]

33. Bobryshev, Y.V.; Ivanova, E.A.; Chistiakov, D.A.; Nikiforov, N.G.; Orekhov, A.N. Macrophages and their role in atherosclerosis: Pathophysiology and transcriptome analysis. Biomed. Res. Int. 2016, 2016, 9582430. [CrossRef]

34. Newby, A.C.; Zaltsman, A.B. Fibrous cap formation or destruction-The critical importance of vascular smooth muscle cell proliferation, migration and matrix formation. Cardiovasc. Res. 1999, 41, 345-360. [CrossRef]

35. Ley, K.; Miller, Y.I.; Hedrick, C.C. Monocyte and macrophage dynamics during atherogenesis. Arter. Thromb. Vasc. Biol. 2011, 31, 1506-1516. [CrossRef] [PubMed]

36. Seimon, T.; Tabas, I. Mechanisms and consequences of macrophage apoptosis in atherosclerosis. J. Lipid Res. 2009, 50, S382-S387. [CrossRef] [PubMed]

37. Finn, A.V.; Nakano, M.; Narula, J.; Kolodgie, F.D.; Virmani, R. Concept of vulnerable/unstable plaque. Arter. Thromb. Vasc. Biol. 2010, 30, 1282-1292. [CrossRef] [PubMed]

38. Martinet, W.; Schrijvers, D.M.; De Meyer, G.R. Necrotic cell death in atherosclerosis. Basic Res. Cardiol. 2011, 106, 749-760. [CrossRef]

39. Galis, Z.S.; Sukhova, G.K.; Lark, M.W.; Libby, P. Increased expression of matrix metalloproteinases and matrix degrading activity in vulnerable regions of human atherosclerotic plaques. J. Clin. Investig. 1994, 94, 2493-2503. [CrossRef]

40. Alpuche, J.; Quirino, L.; Sanchez-Vega, J.T.; Yap, J.; Perez-Campos, E.; Cabrera-Fuentes, H.A. The role of platelets in ischemic conditioning. Cond. Med. 2018, 1, 313-318.

41. Insull, W., Jr. The pathology of atherosclerosis: Plaque development and plaque responses to medical treatment. Am. J. Med. 2009, 122, S3-S14. [CrossRef]

42. Brandt, E.; Ludwig, A.; Petersen, F.; Flad, H.D. Platelet-derived cxc chemokines: Old players in new games. Immunol. Rev. 2000, 177, 204-216. [CrossRef] [PubMed]

43. Kaplan, K.L.; Broekman, M.J.; Chernoff, A.; Lesznik, G.R.; Drillings, M. Platelet alpha-granule proteins: Studies on release and subcellular localization. Blood 1979, 53, 604-618. 
44. Gear, A.R.L.; Camerini, D. Platelet chemokines and chemokine receptors: Linking hemostasis, inflammation, and host defense. Microcirculation 2003, 10, 335-350. [CrossRef] [PubMed]

45. Erbel, C.; Wolf, A.; Lasitschka, F.; Linden, F.; Domschke, G.; Akhavanpoor, M.; Doesch, A.O.; Katus, H.A.; Gleissner, C.A. Prevalence of $\mathrm{m} 4$ macrophages within human coronary atherosclerotic plaques is associated with features of plaque instability. Int. J. Cardiol. 2015, 186, 219-225. [CrossRef] [PubMed]

46. Erbel, C.; Korosoglou, G.; Ler, P.; Akhavanpoor, M.; Domschke, G.; Linden, F.; Doesch, A.O.; Buss, S.J.; Giannitsis, E.; Katus, H.A.; et al. Cxcl4 plasma levels are not associated with the extent of coronary artery disease or with coronary plaque morphology. PLoS ONE 2015, 10, e0141693. [CrossRef]

47. Gleissner, C.A.; Shaked, I.; Little, K.M.; Ley, K. Cxc chemokine ligand 4 induces a unique transcriptome in monocyte-derived macrophages. J. Immunol. 2010, 184, 4810. [CrossRef]

48. Falk, E.; Nakano, M.; Bentzon, J.F.; Finn, A.V.; Virmani, R. Update on acute coronary syndromes: The pathologists' view. Eur. Heart J. 2012, 34, 719-728. [CrossRef]

49. Virmani, R.; Burke, A.P.; Farb, A.; Kolodgie, F.D. Pathology of the vulnerable plaque. J. Am. Coll. Cardiol. 2006, 47, C13-C18. [CrossRef] [PubMed]

50. Chandran, S.; Watkins, J.; Abdul-Aziz, A.; Shafat, M.; Calvert, P.A.; Bowles, K.M.; Flather, M.D.; Rushworth, S.A.; Ryding, A.D. Inflammatory differences in plaque erosion and rupture in patients with st-segment elevation myocardial infarction. J. Am. Heart Assoc. 2017, 6, e005868. [CrossRef] [PubMed]

51. Lafont, A. Basic aspects of plaque vulnerability. Heart 2003, 89, 1262-1267. [CrossRef]

52. Quillard, T.; Franck, G.; Mawson, T.; Folco, E.; Libby, P. Mechanisms of erosion of atherosclerotic plaques. Curr. Opin. Lipidol. 2017, 28, 434-441. [CrossRef] [PubMed]

53. Sugiyama, T.; Yamamoto, E.; Bryniarski, K.; Xing, L.; Lee, H.; Isobe, M.; Libby, P.; Jang, I.-K. Nonculprit plaque characteristics in patients with acute coronary syndrome caused by plaque erosion vs plaque rupture: A 3-vessel optical coherence tomography studyerosion vs rupture nonculprit plaque morphology in acute coronary syndromeerosion vs rupture nonculprit plaque morphology in acute coronary syndrome. Jama Cardiol. 2018, 3, 207-214.

54. Mosser, D.M.; Edwards, J.P. Exploring the full spectrum of macrophage activation. Nat. Rev. Immunol. 2008, 8, 958-969. [CrossRef] [PubMed]

55. Varga, T.; Mounier, R.; Horvath, A.; Cuvellier, S.; Dumont, F.; Poliska, S.; Ardjoune, H.; Juban, G.; Nagy, L.; Chazaud, B. Highly dynamic transcriptional signature of distinct macrophage subsets during sterile inflammation, resolution, and tissue repair. J. Immunol. 2016, 196, 4771. [CrossRef]

56. Randolph, G.J. The fate of monocytes in atherosclerosis. J. Thromb. Haemost. 2009, 7, 28-30. [CrossRef] [PubMed]

57. Nathan, C.; Ding, A. Nonresolving inflammation. Cell 2010, 140, 871-882. [CrossRef] [PubMed]

58. Uysal, H.; Bockermann, R.; Nandakumar, K.S.; Sehnert, B.; Bajtner, E.; Engström, A.; Serre, G.; Burkhardt, H.; Thunnissen, M.M.G.M.; Holmdahl, R. Structure and pathogenicity of antibodies specific for citrullinated collagen type ii in experimental arthritis. J. Exp. Med. 2009, 206, 449. [CrossRef] [PubMed]

59. Mantovani, A.; Allavena, P.; Sica, A.; Balkwill, F. Cancer-related inflammation. Nature 2008, 454, 436. [CrossRef] [PubMed]

60. Galkina, E.; Ley, K. Immune and inflammatory mechanisms of atherosclerosis. Annu. Rev. Immunol. 2009, 27, 165-197. [CrossRef]

61. Mantovani, A.; Sozzani, S.; Locati, M.; Allavena, P.; Sica, A. Macrophage polarization: Tumor-associated macrophages as a paradigm for polarized $\mathrm{m} 2$ mononuclear phagocytes. Trends Immunol. 2002, 23, 549-555. [CrossRef]

62. Biswas, S.K.; Mantovani, A. Macrophage plasticity and interaction with lymphocyte subsets: Cancer as a paradigm. Nat. Immunol. 2010, 11, 889. [CrossRef]

63. Kumar, H.; Kawai, T.; Akira, S. Pathogen recognition by the innate immune system. Int. Rev. Immunol. 2011, 30, 16-34. [CrossRef] [PubMed]

64. Takeuchi, O.; Akira, S. Pattern recognition receptors and inflammation. Cell 2010, 140, 805-820. [CrossRef]

65. Mogensen, T.H. Pathogen recognition and inflammatory signaling in innate immune defenses. Clin. Microbiol. Rev. 2009, 22, 240-273. [CrossRef] [PubMed]

66. Newton, K.; Dixit, V.M. Signaling in innate immunity and inflammation. Cold Spring Harbor Perspect. Biol. 2012, 4, a006049. [CrossRef] 
67. Langrish, C.L.; Chen, Y.; Blumenschein, W.M.; Mattson, J.; Basham, B.; Sedgwick, J.D.; McClanahan, T.; Kastelein, R.A.; Cua, D.J. Il-23 drives a pathogenic $t$ cell population that induces autoimmune inflammation. J. Exp. Med. 2005, 201, 233-240. [CrossRef] [PubMed]

68. Bettelli, E.; Carrier, Y.; Gao, W.; Korn, T.; Strom, T.B.; Oukka, M.; Weiner, H.L.; Kuchroo, V.K. Reciprocal developmental pathways for the generation of pathogenic effector th17 and regulatory t cells. Nature 2006, 441, 235. [CrossRef] [PubMed]

69. Schroder, K.; Hertzog, P.J.; Ravasi, T.; Hume, D.A. Interferon- $\gamma$ : An overview of signals, mechanisms and functions. J. Leukoc. Biol. 2004, 75, 163-189. [CrossRef] [PubMed]

70. Müller, E.; Christopoulos, P.F.; Halder, S.; Lunde, A.; Beraki, K.; Speth, M.; Øynebråten, I.; Corthay, A. Toll-like receptor ligands and interferon- $\gamma$ synergize for induction of antitumor $\mathrm{m} 1$ macrophages. Front. Immunol. 2017, 8, 1383. [CrossRef]

71. Khallou-Laschet, J.; Varthaman, A.; Fornasa, G.; Compain, C.; Gaston, A.-T.; Clement, M.; Dussiot, M.; Levillain, O.; Graff-Dubois, S.; Nicoletti, A.; et al. Macrophage plasticity in experimental atherosclerosis. PLoS ONE 2010, 5, e8852. [CrossRef]

72. Kim, Y.-K.; Oh, S.-Y.; Jeon, S.G.; Park, H.-W.; Lee, S.-Y.; Chun, E.-Y.; Bang, B.; Lee, H.-S.; Oh, M.-H.; Kim, Y.-S.; et al. Airway exposure levels of lipopolysaccharide determine type 1 versus type 2 experimental asthma. J. Immunol. 2007, 178, 5375. [CrossRef]

73. Vandanmagsar, B.; Youm, Y.-H.; Ravussin, A.; Galgani, J.E.; Stadler, K.; Mynatt, R.L.; Ravussin, E.; Stephens, J.M.; Dixit, V.D. The nlrp3 inflammasome instigates obesity-induced inflammation and insulin resistance. Nat. Med. 2011, 17, 179-188. [CrossRef] [PubMed]

74. Pesce, J.T.; Ramalingam, T.R.; Mentink-Kane, M.M.; Wilson, M.S.; El Kasmi, K.C.; Smith, A.M.; Thompson, R.W.; Cheever, A.W.; Murray, P.J.; Wynn, T.A. Arginase-1-expressing macrophages suppress th2 cytokine-driven inflammation and fibrosis. PLoS Pathog. 2009, 5, e1000371. [CrossRef]

75. Martinez, F.O.; Gordon, S.; Locati, M.; Mantovani, A. Transcriptional profiling of the human monocyte-to-macrophage differentiation and polarization: New molecules and patterns of gene expression. J. Immunol. 2006, 177, 7303. [CrossRef]

76. Mantovani, A.; Sica, A.; Sozzani, S.; Allavena, P.; Vecchi, A.; Locati, M. The chemokine system in diverse forms of macrophage activation and polarization. Trends Immunol. 2004, 25, 677-686. [CrossRef] [PubMed]

77. Hart, P.H.; Burgess, D.R.; Vitti, G.F.; Hamilton, J.A. Interleukin-4 stimulates human monocytes to produce tissue-type plasminogen activator. Blood 1989, 74, 1222.

78. Gratchev, A.; Guillot, P.; Hakiy, N.; Politz, O.; Orfanos, C.E.; Schledzewski, K.; Goerdt, S. Alternatively activated macrophages differentially express fibronectin and its splice variants and the extracellular matrix protein ßig-h3. Scand. J. Immunol. 2001, 53, 386-392. [CrossRef]

79. Borthwick, L.A.; Wynn, T.A.; Fisher, A.J. Cytokine mediated tissue fibrosis. Biochim. Et Biophys. Acta (Bba) Mol. Basis Dis. 2013, 1832, 1049-1060. [CrossRef] [PubMed]

80. Van Dyken, S.J.; Locksley, R.M. Interleukin-4- and interleukin-13-mediated alternatively activated macrophages: Roles in homeostasis and disease. Annu. Rev. Immunol. 2013, 31, 317-343. [CrossRef] [PubMed]

81. Martinez, F.O.; Sica, A.; Mantovani, A.; Locati, M. Macrophage activation and polarization. Front. Biosci. 2008, 13, 453-461. [CrossRef]

82. Murray, P.J.; Wynn, T.A. Protective and pathogenic functions of macrophage subsets. Nat. Rev. Immunol. 2011, 11, 723. [CrossRef] [PubMed]

83. Hashimoto, D.; Chow, A.; Noizat, C.; Teo, P.; Beasley, M.B.; Leboeuf, M.; Becker, C.D.; See, P.; Price, J.; Lucas, D.; et al. Tissue-resident macrophages self-maintain locally throughout adult life with minimal contribution from circulating monocytes. Immunity 2013, 38, 792-804. [CrossRef]

84. Hoeffel, G.; Wang, Y.; Greter, M.; See, P.; Teo, P.; Malleret, B.; Leboeuf, M.; Low, D.; Oller, G.; Almeida, F.; et al. Adult langerhans cells derive predominantly from embryonic fetal liver monocytes with a minor contribution of yolk sac-derived macrophages. J. Exp. Med. 2012, 209, 1167. [CrossRef]

85. Guilliams, M.; De Kleer, I.; Henri, S.; Post, S.; Vanhoutte, L.; De Prijck, S.; Deswarte, K.; Malissen, B.; Hammad, H.; Lambrecht, B.N. Alveolar macrophages develop from fetal monocytes that differentiate into long-lived cells in the first week of life via gm-csf. J. Exp. Med. 2013, 210, 1977. [CrossRef] 
86. Ginhoux, F.; Greter, M.; Leboeuf, M.; Nandi, S.; See, P.; Gokhan, S.; Mehler, M.F.; Conway, S.J.; Ng, L.G.; Stanley, E.R.; et al. Fate mapping analysis reveals that adult microglia derive from primitive macrophages. Science 2010, 330, 841. [CrossRef] [PubMed]

87. Davies, L.C.; Jenkins, S.J.; Allen, J.E.; Taylor, P.R. Tissue-resident macrophages. Nat. Immunol. 2013, 14, 986. [CrossRef]

88. Stahl, E.C.; Haschak, M.J.; Popovic, B.; Brown, B.N. Macrophages in the aging liver and age-related liver disease. Front. Immunol. 2018, 9, 2795. [CrossRef]

89. Pinto, A.R.; Godwin, J.W.; Chandran, A.; Hersey, L.; Ilinykh, A.; Debuque, R.; Wang, L.; Rosenthal, N.A. Age-related changes in tissue macrophages precede cardiac functional impairment. Aging 2014, 6, 399-413. [CrossRef]

90. Sager, H.B.; Hulsmans, M.; Lavine, K.J.; Moreira, M.B.; Heidt, T.; Courties, G.; Sun, Y.; Iwamoto, Y.; Tricot, B.; Khan, O.F.; et al. Proliferation and recruitment contribute to myocardial macrophage expansion in chronic heart failure. Circ. Res. 2016, 119, 853-864. [CrossRef]

91. Epelman, S.; Lavine, K.J.; Beaudin, A.E.; Sojka, D.K.; Carrero, J.A.; Calderon, B.; Brija, T.; Gautier, E.L.; Ivanov, S.; Satpathy, A.T.; et al. Embryonic and adult-derived resident cardiac macrophages are maintained through distinct mechanisms at steady state and during inflammation. Immunity 2014, 40, 91-104. [CrossRef]

92. Leid, J.; Carrelha, J.; Boukarabila, H.; Epelman, S.; Jacobsen, S.E.W.; Lavine, K.J. Primitive embryonic macrophages are required for coronary development and maturation. Circ. Res. 2016, 118, 1498-1511. [CrossRef] [PubMed]

93. Molawi, K.; Wolf, Y.; Kandalla, P.K.; Favret, J.; Hagemeyer, N.; Frenzel, K.; Pinto, A.R.; Klapproth, K.; Henri, S.; Malissen, B.; et al. Progressive replacement of embryo-derived cardiac macrophages with age. J. Exp. Med. 2014, 211, 2151-2158. [CrossRef]

94. Serbina, N.V.; Pamer, E.G. Monocyte emigration from bone marrow during bacterial infection requires signals mediated by chemokine receptor ccr2. Nat. Immunol. 2006, 7, 311. [CrossRef] [PubMed]

95. Aurora, A.B.; Porrello, E.R.; Tan, W.; Mahmoud, A.I.; Hill, J.A.; Bassel-Duby, R.; Sadek, H.A.; Olson, E.N. Macrophages are required for neonatal heart regeneration. J. Clin. Investig. 2014, 124, 1382-1392. [CrossRef] [PubMed]

96. Lavine, K.J.; Epelman, S.; Uchida, K.; Weber, K.J.; Nichols, C.G.; Schilling, J.D.; Ornitz, D.M.; Randolph, G.J.; Mann, D.L. Distinct macrophage lineages contribute to disparate patterns of cardiac recovery and remodeling in the neonatal and adult heart. Proc. Natl. Acad. Sci. USA 2014, 111, 16029-16034. [CrossRef]

97. Bajpai, G.; Bredemeyer, A.; Li, W.; Zaitsev, K.; Koenig, A.L.; Lokshina, I.; Mohan, J.; Ivey, B.; Hsiao, H.M.; Weinheimer, C.; et al. Tissue resident ccr2- and ccr2+ cardiac macrophages differentially orchestrate monocyte recruitment and fate specification following myocardial injury. Circ. Res. 2019, 124, 263-278. [CrossRef] [PubMed]

98. Robbins, C.S.; Chudnovskiy, A.; Rauch, P.J.; Figueiredo, J.-L.; Iwamoto, Y.; Gorbatov, R.; Etzrodt, M.; Weber, G.F.; Ueno, T.; van Rooijen, N.; et al. Extramedullary hematopoiesis generates ly-6c(high) monocytes that infiltrate atherosclerotic lesions. Circulation 2012, 125, 364-374. [CrossRef]

99. Swirski, F.K.; Libby, P.; Aikawa, E.; Alcaide, P.; Luscinskas, F.W.; Weissleder, R.; Pittet, M.J. Ly-6chi monocytes dominate hypercholesterolemia-associated monocytosis and give rise to macrophages in atheromata. J. Clin. Investig. 2007, 117, 195-205. [CrossRef]

100. Tacke, F.; Alvarez, D.; Kaplan, T.J.; Jakubzick, C.; Spanbroek, R.; Llodra, J.; Garin, A.; Liu, J.; Mack, M.; van Rooijen, N.; et al. Monocyte subsets differentially employ ccr2, ccr5, and cx3cr1 to accumulate within atherosclerotic plaques. J. Clin. Investig. 2007, 117, 185-194. [CrossRef]

101. Combadière, C.; Potteaux, S.; Rodero, M.; Simon, T.; Pezard, A.; Esposito, B.; Merval, R.; Proudfoot, A.; Tedgui, A.; Mallat, Z. Combined inhibition of Ccl2, Cx3cr1 and Ccr5 abrogates Ly6chi and Ly6clo monocytosis and almost abolishes atherosclerosis in hypercholesterolemic mice. Circulation 2008, 117, 1649-1657. [CrossRef]

102. Pinto, A.R.; Paolicelli, R.; Salimova, E.; Gospocic, J.; Slonimsky, E.; Bilbao-Cortes, D.; Godwin, J.W.; Rosenthal, N.A. An abundant tissue macrophage population in the adult murine heart with a distinct alternatively-activated macrophage profile. PLoS ONE 2012, 7, e36814. [CrossRef] [PubMed]

103. Heidt, T.; Courties, G.; Dutta, P.; Sager, H.B.; Sebas, M.; Iwamoto, Y.; Sun, Y.; Silva, N.D.; Panizzi, P.; Laan, A.M.v.d.; et al. Differential contribution of monocytes to heart macrophages in steady-state and after myocardial infarction. Circ. Res. 2014, 115, 284-295. [CrossRef] [PubMed] 
104. Leuschner, F.; Dutta, P.; Gorbatov, R.; Novobrantseva, T.I.; Donahoe, J.S.; Courties, G.; Lee, K.M.; Kim, J.I.; Markmann, J.F.; Marinelli, B.; et al. Therapeutic sirna silencing in inflammatory monocytes in mice. Nat. Biotechnol. 2011, 29, 1005-1010. [CrossRef] [PubMed]

105. DeBerge, M.; Yeap, X.Y.; Dehn, S.; Zhang, S.; Grigoryeva, L.; Misener, S.; Procissi, D.; Zhou, X.; Lee, D.C.; Muller, W.A.; et al. Mertk cleavage on resident cardiac macrophages compromises repair after myocardial ischemia reperfusion injury. Circ. Res. 2017, 121, 930-940. [CrossRef] [PubMed]

106. Yabluchanskiy, A.; Ma, Y.; Chiao, Y.A.; Lopez, E.F.; Voorhees, A.P.; Toba, H.; Hall, M.E.; Han, H.-C.; Lindsey, M.L.; Jin, Y.-F. Cardiac aging is initiated by matrix metalloproteinase-9-mediated endothelial dysfunction. Am. J. Physiol. Heart Circ. Physiol. 2014, 306, H1398-H1407. [CrossRef]

107. Lindsey, M.L.; Goshorn, D.K.; Squires, C.E.; Escobar, G.P.; Hendrick, J.W.; Mingoia, J.T.; Sweterlitsch, S.E.; Spinale, F.G. Age-dependent changes in myocardial matrix metalloproteinase/tissue inhibitor of metalloproteinase profiles and fibroblast function. Cardiovasc. Res. 2005, 66, 410-419. [CrossRef] [PubMed]

108. Lin, J.; Lopez, E.F.; Jin, Y.; Van Remmen, H.; Bauch, T.; Han, H.-C.; Lindsey, M.L. Age-related cardiac muscle sarcopenia: Combining experimental and mathematical modeling to identify mechanisms. Exp. Gerontol. 2008, 43, 296-306. [CrossRef]

109. Chiao, Y.A.; Ramirez, T.A.; Zamilpa, R.; Okoronkwo, S.M.; Dai, Q.; Zhang, J.; Jin, Y.-F.; Lindsey, M.L. Matrix metalloproteinase-9 deletion attenuates myocardial fibrosis and diastolic dysfunction in ageing mice. Cardiovasc. Res. 2012, 96, 444-455. [CrossRef]

110. DeWood, M.A.; Spores, J.; Notske, R.; Mouser, L.T.; Burroughs, R.; Golden, M.S.; Lang, H.T. Prevalence of total coronary occlusion during the early hours of transmural myocardial infarction. New Engl. J. Med. 1980, 303, 897-902. [CrossRef]

111. Bentzon Jacob, F.; Otsuka, F.; Virmani, R.; Falk, E. Mechanisms of plaque formation and rupture. Circ. Res. 2014, 114, 1852-1866. [CrossRef]

112. Jennings Robert, B. Historical perspective on the pathology of myocardial ischemia/reperfusion injury. Circ. Res. 2013, 113, 428-438. [CrossRef]

113. Sayen, J.J.; Sheldon, W.F.; Peirce, G.; Kuo, P.T. Polarographic oxygen, the epicardial electrocardiogram and muscle contraction in experimental acute regional ischemia of the left ventricle. Circ. Res. 1958, 6, 779-798. [CrossRef]

114. Fujiwara, Y.; Fujiwara, H.; Matsuda, M.; Onodera, T.; Ishida, M.; Kawamura, A.; Okamoto, Y.; Ban, T.; Kawai, C. Reperfusion injury in dog hearts with permanent occlusion of a coronary artery, probably due to reperfusion via collateral vessels. Int. J. Cardiol. 1991, 30, 275-284. [CrossRef]

115. Jennings, R.B.; Sommers, H.M.; Smyth, G.A.; Flack, H.A.; Linn, H. Myocardial necrosis induced by temporary occlusion of a coronary artery in the dog. Arch. Pathol. 1960, 70, 68-78. [PubMed]

116. Jennings, R.; Murry, C.; Steenbergen, C.; Reimer, K.A. Development of cell injury in sustained acute ischemia. Circulation 1990, 82, II2-II12.

117. Nahrendorf, M.; Pittet, M.J.; Swirski, F.K. Monocytes: Protagonists of infarct inflammation and repair after myocardial infarction. Circulation 2010, 121, 2437-2445. [CrossRef] [PubMed]

118. Ong, S.B.; Hernandez-Resendiz, S.; Crespo-Avilan, G.E.; Mukhametshina, R.T.; Kwek, X.Y.; Cabrera-Fuentes, H.A.; Hausenloy, D.J. Inflammation following acute myocardial infarction: Multiple players, dynamic roles, and novel therapeutic opportunities. Pharmacol. Ther. 2018, 186, 73-87. [CrossRef]

119. Andreadou, I.; Cabrera-Fuentes, H.A.; Devaux, Y.; Frangogiannis, N.G.; Frantz, S.; Guzik, T.; Liehn, E.; Gomes, C.P.; Gomes, C.; Schulz, R.; et al. Immune cells as targets for cardioprotection: New players and novel therapeutic opportunities. Cardiovasc. Res. Available online: https:/academic.oup.com/cardiovascres/ advance-article-abstract/doi/10.1093/cvr/cvz050/5368489 (accessed on 2 March 2019).

120. Hernandez-Resendiz, S.; Chinda, K.; Ong, S.B.; Cabrera-Fuentes, H.; Zazueta, C.; Hausenloy, D.J. The role of redox dysregulation in the inflammatory response to acute myocardial ischaemia-reperfusion injury adding fuel to the fire. Curr. Med. Chem. 2018, 25, 1275-1293. [CrossRef]

121. Yellon, D.M.; Hausenloy, D.J. Myocardial reperfusion injury. New Engl. J. Med. 2007, 357, 1121-1135. [CrossRef]

122. Prabhu, S.D.; Frangogiannis, N.G. The biological basis for cardiac repair after myocardial infarction: From inflammation to fibrosis. Circ. Res. 2016, 119, 91-112. [CrossRef] 
123. Dewald, O.; Zymek, P.; Winkelmann, K.; Koerting, A.; Ren, G.; Abou-Khamis, T.; Michael Lloyd, H.; Rollins Barrett, J.; Entman Mark, L.; Frangogiannis Nikolaos, G. Ccl2/monocyte chemoattractant protein-1 regulates inflammatory responses critical to healing myocardial infarcts. Circ. Res. 2005, 96, 881-889. [CrossRef]

124. Kaikita, K.; Hayasaki, T.; Okuma, T.; Kuziel, W.A.; Ogawa, H.; Takeya, M. Targeted deletion of cc chemokine receptor 2 attenuates left ventricular remodeling after experimental myocardial infarction. Am. J. Pathol. 2004, 165, 439-447. [CrossRef]

125. Nahrendorf, M.; Swirski, F.K.; Aikawa, E.; Stangenberg, L.; Wurdinger, T.; Figueiredo, J.-L.; Libby, P.; Weissleder, R.; Pittet, M.J. The healing myocardium sequentially mobilizes two monocyte subsets with divergent and complementary functions. J. Exp. Med. 2007, 204, 3037-3047. [CrossRef]

126. Jung, K.; Kim, P.; Leuschner, F.; Gorbatov, R.; Kim, J.K.; Ueno, T.; Nahrendorf, M.; Yun, S.H. Endoscopic time-lapse imaging of immune cells in infarcted mouse hearts. Circ. Res. 2013, 112, 891-899. [CrossRef]

127. Gautier, E.L.; Shay, T.; Miller, J.; Greter, M.; Jakubzick, C.; Ivanov, S.; Helft, J.; Chow, A.; Elpek, K.G.; Gordonov, S.; et al. Gene-expression profiles and transcriptional regulatory pathways that underlie the identity and diversity of mouse tissue macrophages. Nat. Immunol. 2012, 13, 1118-1128. [CrossRef]

128. Troidl, C.; Möllmann, H.; Nef, H.; Masseli, F.; Voss, S.; Szardien, S.; Willmer, M.; Rolf, A.; Rixe, J.; Troidl, K.; et al. Classically and alternatively activated macrophages contribute to tissue remodelling after myocardial infarction. J. Cell. Mol. Med. 2009, 13, 3485-3496. [CrossRef]

129. Yan, X.; Anzai, A.; Katsumata, Y.; Matsuhashi, T.; Ito, K.; Endo, J.; Yamamoto, T.; Takeshima, A.; Shinmura, K.; Shen, W.; et al. Temporal dynamics of cardiac immune cell accumulation following acute myocardial infarction. J. Mol. Cell. Cardiol. 2013, 62, 24-35. [CrossRef]

130. Frantz, S.; Nahrendorf, M. Cardiac macrophages and their role in ischaemic heart disease. Cardiovasc. Res. 2014, 102, 240-248. [CrossRef]

131. Wan, E.; Yeap Xin, Y.; Dehn, S.; Terry, R.; Novak, M.; Zhang, S.; Iwata, S.; Han, X.; Homma, S.; Drosatos, K.; et al. Enhanced efferocytosis of apoptotic cardiomyocytes through myeloid-epithelial-reproductive tyrosine kinase links acute inflammation resolution to cardiac repair after infarction. Circ. Res. 2013, 113, 1004-1012. [CrossRef]

132. Frangogiannis, N.G. Inflammation in cardiac injury, repair and regeneration. Curr. Opin. Cardiol. 2015, 30, 240-245. [CrossRef]

133. Shiraishi, M.; Shintani, Y.; Shintani, Y.; Ishida, H.; Saba, R.; Yamaguchi, A.; Adachi, H.; Yashiro, K.; Suzuki, K. Alternatively activated macrophages determine repair of the infarcted adult murine heart. J. Clin. Investig. 2016, 126, 2151-2166. [CrossRef] [PubMed]

134. Stancu, C.; Sima, A. Statins: Mechanism of action and effects. J. Cell Mol. Med. 2001, 5, 378-387. [CrossRef] [PubMed]

135. Ludman, A.; Venugopal, V.; Yellon, D.M.; Hausenloy, D.J. Statins and cardioprotection-More than just lipid lowering? Pharmacol. Ther. 2009, 122, 30-43. [CrossRef] [PubMed]

136. Kwak, B.; Mulhaupt, F.; Myit, S.; Mach, F. Statins as a newly recognized type of immunomodulator. Nat. Med. 2000, 6, 1399-1402. [CrossRef] [PubMed]

137. Ghittoni, R.; Napolitani, G.; Benati, D.; Ulivieri, C.; Patrussi, L.; Laghi Pasini, F.; Lanzavecchia, A.; Baldari, C.T. Simvastatin inhibits the mhc class ii pathway of antigen presentation by impairing ras superfamily gtpases. Eur. J. Immunol. 2006, 36, 2885-2893. [CrossRef] [PubMed]

138. Di Raimondo, D.; Tuttolomondo, A.; Butta, C.; Miceli, S.; Licata, G.; Pinto, A. Effects of ace-inhibitors and angiotensin receptor blockers on inflammation. Curr. Pharm. Des. 2012, 18, 4385-4413. [CrossRef] [PubMed]

139. Schreckenberg, R.; Weber, P.; Cabrera-Fuentes, H.A.; Steinert, I.; Preissner, K.T.; Bencsik, P.; Sarkozy, M.; Csonka, C.; Ferdinandy, P.; Schulz, R.; et al. Mechanism and consequences of the shift in cardiac arginine metabolism following ischaemia and reperfusion in rats. Thromb. Haemost. 2015, 113, 482-493.

140. Bernstein, K.E.; Ong, F.S.; Blackwell, W.L.; Shah, K.H.; Giani, J.F.; Gonzalez-Villalobos, R.A.; Shen, X.Z.; Fuchs, S.; Touyz, R.M. A modern understanding of the traditional and nontraditional biological functions of angiotensin-converting enzyme. Pharm. Rev. 2013, 65, 1-46. [CrossRef]

141. Leuschner, F.; Panizzi, P.; Chico-Calero, I.; Lee, W.W.; Ueno, T.; Cortez-Retamozo, V.; Waterman, P.; Gorbatov, R.; Marinelli, B.; Iwamoto, Y.; et al. Angiotensin-converting enzyme inhibition prevents the release of monocytes from their splenic reservoir in mice with myocardial infarction. Circ. Res. 2010, 107, 1364-1373. [CrossRef] [PubMed] 
142. Soejima, H.; Ogawa, H.; Yasue, H.; Kaikita, K.; Takazoe, K.; Nishiyama, K.; Misumi, K.; Miyamoto, S.; Yoshimura, M.; Kugiyama, K.; et al. Angiotensin-converting enzyme inhibition reduces monocyte chemoattractant protein-1 and tissue factor levels in patients with myocardial infarction. J. Am. Coll. Cardiol. 1999, 34, 983-988. [CrossRef]

143. Porrello, E.R.; Mahmoud, A.I.; Simpson, E.; Hill, J.A.; Richardson, J.A.; Olson, E.N.; Sadek, H.A. Transient regenerative potential of the neonatal mouse heart. Science (New York N.Y.) 2011, 331, 1078-1080. [CrossRef] [PubMed]

144. Dick, S.A.; Macklin, J.A.; Nejat, S.; Momen, A.; Clemente-Casares, X.; Althagafi, M.G.; Chen, J.; Kantores, C.; Hosseinzadeh, S.; Aronoff, L.; et al. Self-renewing resident cardiac macrophages limit adverse remodeling following myocardial infarction. Nat. Immunol. 2019, 20, 29-39. [CrossRef] [PubMed]

145. Hasan, A.S.; Luo, L.; Yan, C.; Zhang, T.-X.; Urata, Y.; Goto, S.; Mangoura, S.A.; Abdel-Raheem, M.H.; Zhang, S.; Li, T.-S. Cardiosphere-derived cells facilitate heart repair by modulating $\mathrm{m} 1 / \mathrm{m} 2$ macrophage polarization and neutrophil recruitment. PLOS ONE 2016, 11, e0165255. [CrossRef] [PubMed]

146. de Couto, G.; Liu, W.; Tseliou, E.; Sun, B.; Makkar, N.; Kanazawa, H.; Arditi, M.; Marbán, E. Macrophages mediate cardioprotective cellular postconditioning in acute myocardial infarction. J. Clin. Investig. 2015, 125, 3147-3162. [CrossRef]

147. Smith, R.R.; Barile, L.; Cho, H.C.; Leppo, M.K.; Hare, J.M.; Messina, E.; Giacomello, A.; Abraham, M.R.; Marbán, E. Regenerative potential of cardiosphere-derived cells expanded from percutaneous endomyocardial biopsy specimens. Circulation 2007, 115, 896-908. [CrossRef] [PubMed]

148. Madonna, R.; Van Laake, L.W.; Botker, H.E.; Davidson, S.M.; De Caterina, R.; Engel, F.B.; Eschenhagen, T.; Fernandez-Aviles, F.; Hausenloy, D.J.; Hulot, J.S.; et al. Esc working group on cellular biology of the heart: Position paper for cardiovascular research: Tissue engineering strategies combined with cell therapies for cardiac repair in ischaemic heart disease and heart failure. Cardiovasc. Res. 2019, 115, 488-500. [CrossRef]

149. Kanazawa, H.; Tseliou, E.; Malliaras, K.; Yee, K.; Dawkins, J.F.; De Couto, G.; Smith, R.R.; Kreke, M.; Seinfeld, J.; Middleton, R.C.; et al. Cellular postconditioning. Circ. Heart Fail. 2015, 8, 322-332. [CrossRef]

150. Shen, D.; Cheng, K.; Marbán, E. Dose-dependent functional benefit of human cardiosphere transplantation in mice with acute myocardial infarction. J. Cell. Mol. Med. 2012, 16, 2112-2116. [CrossRef]

151. Malliaras, K.; Li, T.-S.; Luthringer, D.; Terrovitis, J.; Cheng, K.; Chakravarty, T.; Galang, G.; Zhang, Y.; Schoenhoff, F.; Van Eyk, J.; et al. Safety and efficacy of allogeneic cell therapy in infarcted rats transplanted with mismatched cardiosphere-derived cells. Circulation 2012, 125, 100-112. [CrossRef]

152. Li, T.-S.; Cheng, K.; Malliaras, K.; Smith, R.R.; Zhang, Y.; Sun, B.; Matsushita, N.; Blusztajn, A.; Terrovitis, J.; Kusuoka, H.; et al. Direct comparison of different stem cell types and subpopulations reveals superior paracrine potency and myocardial repair efficacy with cardiosphere-derived cells. J. Am. Coll. Cardiol. 2012, 59, 942-953. [CrossRef]

153. Cheng, K.; Malliaras, K.; Smith, R.R.; Shen, D.; Sun, B.; Blusztajn, A.; Xie, Y.; Ibrahim, A.; Aminzadeh, M.A.; Liu, W.; et al. Human cardiosphere-derived cells from advanced heart failure patients exhibit augmented functional potency in myocardial repair. Jacc. Heart Fail. 2014, 2, 49-61. [CrossRef] [PubMed]

(C) 2019 by the authors. Licensee MDPI, Basel, Switzerland. This article is an open access article distributed under the terms and conditions of the Creative Commons Attribution (CC BY) license (http://creativecommons.org/licenses/by/4.0/). 